Ilya Gruntov ${ }^{\dagger}$, Olga Mazoł

${ }^{+}$Institute of Linguistics of the Russian Academy of Sciences / Yandex, Moscow; altaica@yandex.ru

$\ddagger$ Russian State University for the Humanities / Higher School of Economics, Moscow; olga_mazo@list.ru

\title{
Mongghul, Mangghuer and beyond: estimating the proximity
}

\begin{abstract}
The paper's chief goal is to evaluate the intensity of relations between various idioms of Mongolic languages within the Qinghai-Gansu Sprachbund, with special focus on Mangghuer and Mongghul dialects. On the basis of 58 grammatical and phonological shared innovations we attempt to deepen our understanding of the pathways and patterns of language change taking place in this area.
\end{abstract}

Keywords: Qinghai-Gansu Sprachbund; language contacts; Monguor language; Shirongolic languages; Mangghuer language; Mongghul language; Mongolic languages; shared innovations.

Mongghul and Mangghuer are two closely related endangered languages of the Mongolic family, spoken in Qinghai and Gansu provinces of China. For a long time they have been generally considered as a single Monguor language with two main dialects. Although the division of these idioms into at least two languages has gradually become accepted among specialists, new linguistic works continue to be published in which both languages are still referred to as Monguor dialects.

Our paper is an attempt to clarify and evaluate the intensity of relations between various idioms of QG Mongolic languages with special focus on Mangghuer and Mongghul, and to investigate various isoglosses within these languages. We do not discuss here the peculiarities and features shared by all QG Mongolic languages.

The languages of the region belong to the so called Qinghai-Gansu Sprachbund (Yellow River language union, Amdo Sprachbund, the Northwest China Sprachbund, etc., see Dwyer 1992, 1995; Slater 2003a; Janhunen 2007, 2012). This Sprachbund includes languages and dialects of four families: Sinitic (Northwestern Mandarin, Gangou, Tangwang, Wutun, Linxia /Hezhou/), Bodic (Amdo Tibetan), Turkic (Salar, Western Yugurs), and Mongolic (Mongghul, Mangghuer, Dongxiang, Baoan /Qinghai and Gansu varieties/, Kangjia, Shira Yughur).

Due to intensive interaction, languages of different types started to share phonetic, morphologic and syntactic features. Many of the speakers are proficient in two or more languages or dialects: Standard Chinese (Putonghua), Qinghai Mandarin, Amdo Tibetan. The choice of lingua franca in the region depends on religious identity: it is Amdo Tibetan for Buddhists, but Northwestern Mandarin for Muslims. Such interaction has caused serious changes in language structure and the appearance of idioms like Wutun, Gangou, Tangwang which are sometimes even labelled in linguistic works as "creole" or "hybrid".

The official Chinese classification of minorities refers to Mongghul and Mangghuer communities as Tu people ( $\mathrm{Tuzu}$ 土族). Actually, Tuzu is one of the 55 national minorities, and it is a common name for people of different nationalities and speakers of different languages: Mongol-speaking Mongghul, Mangghuer, and Qinghai Baoan (Gansu Baoan are officially recognized as a separate Baoan nationality); speakers of Wutun (a Sinitic language); and Tibetanspeaking Shaowu Tuzu, who were considered Tibetans until 1986 (Janhunen et al. 2007). 
According to Poston and Xiong (2014: 118), the number of the Monguor in 2010 was 289,565. The number of Monguor speakers in 2000 was about 100,000 (Zhang 2012: 37).

The Mangghuer (or Minhe Mangghuer, минхә) speakers live in Minhe Hui and Tu Autonomous County (Qinghai); their number is approximately 25,000 (Slater 2003b: 307). Little is known about dialectal varieties of Mangghuer. Slater (2003b: 308) states that "Speakers report noticeable dialect differences, particularly in the areas of phonology and lexicon, but a systematic study has not yet been undertaken.”

Mongghul (also named Huzhu Mongghul, xyщ,3y) speakers live in Huzhu Tu Autonomous County, Datong Hui and Tu Autonomous County, Ledu district, Menyuan Hui Autonomous County (Qinghai), Tianzhu Tibetan Autonomous County, Yongdeng county, Linxia county (Gansu) (Junast 1981: 1, Georg 2003: 286).

There are two main theories about the origins of the Monguor: the 'Mongol theory' and the 'Tuyuhun theory'. According to the first one, the Monguor are descendants of Mongol soldiers who arrived into the region in the $13^{\text {th }}$ century. The second theory suggests that the Monguor are the descendants of the people of the Tuyuhun (吐谷浑) kingdom ( $3^{\text {th }}-7^{\text {th }}$ century) (for details see e.g. Cui Yonghong et al. 2015; Georg 2003: 287; Slater 2003a: 16-19; Schram 1954-1961; Lü Jianfu 2002; Li Keyu 1993, 2008, etc.).

Dan $\mathrm{Xu}$ and Shaoqing Wen (2017: 60-61) have studied Y-chromosomal data of the Huzhu Monguors. According to the results, the most frequent lineages were haplogroups R1a1a-M17 $13,22 \%$ (predominant in some Turkic-speaking populations), D1-M15 10, 74\% (associated with Tibeto-Burman populations), O3-M122, O3a2c1a-M117, O3a1c-002611 20.7\% (predominant in Han and Hui populations, but rare or absent in Mongolic and Turkic populations). Haplogroups C3*-M217, C3c-M48 and C3d-M407, the common paternal lineage in Mongolic-speaking populations, appear with relatively low frequency $-9,09 \%$.

De Smedt and Mostaert (1929: 145) and later Todaeva (1973: 11) list three Mongghul dialects: Naringhol, Halchighol, and Fulaan Nura. Janhunen (2006: 28; Janhunen et al. 2007: 179180) considers Halchighol and Naringhol to be two separate languages. Georg (2003: 286) mentions a possible dialectal variety of Mongghul spoken in Menyuan Hui Autonomous County (Qinghai). Faehndrich (2007: 11-17) discusses Naringhol, Halchighol, Karlong (Fulaan Nura), Datong (possibly extinct), Tianzhu, Menyuan, Ping'an varieties. She proposes the following tentative Monguor family tree (Faehndrich 2007: 242):

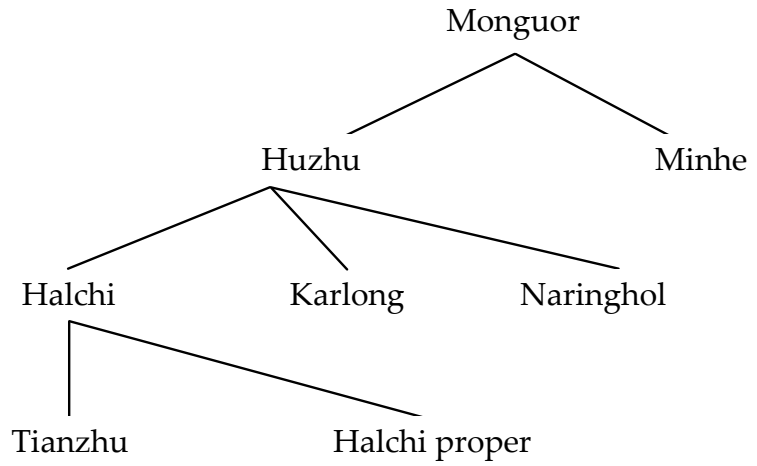

The first records on the Monguor people (who were called 'Dada', 'Damin', 'Tuda', 'Tumin', and 'Turen') can be found in documents going back to the Ming dynasty (1368-1644; see Cui Yonghong et al. 2015: 18). The Catholic missionary Évariste-Régis Huc described Mangghuer spoken in Sanchuan as a Mongolic language with Chinese and Tibetan elements (Huc 1850: 36). N. M. Przheval'skii (1875: 199) in his materials gave a description of the local people of Qing- 
hai named Daldy. G. N. Potanin mentions that the Chinese and the Dongxiang called them Turen, while other Mongols gave them the name of Dalda or Doldo (Potanin 1893: I, 342; II, 410). He included some Mangghuer words and data on other Shirongol languages in the materials of the expedition (1893: II, 410-425).

Monguor varieties are not evenly represented in scientific literature. Halchighol seems to be the most frequent idiom in linguistic descriptions. Dominik Schröder published a description of the religious life (1952-1953), two texts (1959-1970), and description of grammar (1964). "Mongorskii yazik" (Todaeva 1973) contains a detailed grammar of Halchighol Monguor with data on Naringhol, Fulaan Nara, Minhe, and different types of texts. Other Monggul materials based on Halchighol data are the grammar descriptions of Junast (1981) (with some comparison with Mangghuer), that of Chingeltei and Li Keyu (1988) (with comparison with other Mongolic languages), vocabularies of Hasbaatar (1985) and Li Keyu (1988), materials of Chingeltei (1986), Chuluu (1994), short descriptions of Georg (2003) and Sinor (1952), etc. Dpal-ldan-bkrashis, K. Slater et al. (1996) published materials and a small dictionary of both Mangghuer and Mongghul. Different aspects of Mongghul phonetics, grammar, vocabulary and dialectology are discussed in Róna-Tas (1960, 1962, 1966), Chingeltei (1989), Kakudo (1987, 1997), etc.

Antoine Mostaert and Albrecht de Smedt wrote the first detailed description of Naringhol Mongghul including phonetics (1929-1931), grammar (1945), and a big Monguor-French dictionary (1933).

Faehndrich (2007) focused her dissertation on the Fulaan Nura or Karlong.

The Mangghuer grammar was published by Slater (2003a); sketches of Mangghuer grammar were written by Junast and Li Keyu (1982), Slater (2003b).

The phonology of the Mongol languages of Qinghai-Gansu is studied in detail by Nugteren (2011), who also compared some grammar and lexical features. The position of Monguor languages within the Mongolic family was discussed in many papers, such as Sanzheev (1952), Poppe (1955), Luwsanwandan (1959), Doerfer (1964), Binnick (1987), Nugteren (1997, 2011: 34-56), Rybatzki (2003: 386), Gruntov, Mazo (2015), etc.

Below we shall discuss the characteristics that differentiate Mangghuer from Mongghul, and Mongghul dialects from each other; the focus will be on what features they share with the other Mongolic languages of the region. In our paper we do not consider lexical borrowings (e.g. borrowing of numerals), but borrowing of grammatical elements is taken into account.

\section{Phonetics}

Mangghuer (Slater 2003b: 309)

Consonants

\begin{tabular}{l|c|c|c|c|c|c}
\hline & labial & alveolar & retroflex & palatal & velar & uvular \\
\hline stop & $\mathrm{p} \mathrm{b}$ & $\mathrm{td}$ & & & $\mathrm{kg}$ & $\mathrm{q} \mathrm{G}$ \\
\hline affricate & & $\mathrm{ts}(\mathrm{c})^{1} \mathrm{dz}(\mathrm{z})$ & $\mathrm{ts}(\mathrm{ch}) \mathrm{dz}(\mathrm{zh})$ & $\mathrm{t} \varphi(\mathrm{q}) \mathrm{d}(\mathrm{j})$ & & \\
\hline fricative & $\mathrm{f}$ & $\mathrm{s}$ & $\mathrm{s}(\mathrm{sh})$ & $\mathrm{G}(\mathrm{x})$ & $\mathrm{h}$ & \\
\hline nasal & $\mathrm{m}$ & $\mathrm{n}$ & & & $\mathrm{y}$ & \\
\hline liquid & & $\mathrm{l}$ & $\mathrm{r}$ & & & \\
\hline glide & $\mathrm{w}$ & & & $\mathrm{j}$ & & \\
\hline
\end{tabular}

${ }^{1}$ Many authors use pinyin-based orthography; the corresponding transcriptions are given in brackets. 
Fricative $f$ generally occurs in Chinese borrowings.

Five short vowels: /a/, /e/,/i/,/o/, and /u/.

Mongghul (Georg 2003: 290)

Consonants

\begin{tabular}{l|c|c|c|c|c|c}
\hline & labial & alveolar & retroflex & palatal & velar & uvular \\
\hline stop & $\mathrm{p} \mathrm{b}$ & $\mathrm{td}$ & & & $\mathrm{kg}$ & $\mathrm{G}$ \\
\hline affricate & & $\mathrm{ts}(\mathrm{c}) \mathrm{dz}(\mathrm{z})$ & $\mathrm{ts}(\mathrm{ch}) \mathrm{dz}(\mathrm{zh})$ & $\mathrm{tc}(\mathrm{q}) \mathrm{d} \mathrm{f}(\mathrm{j})$ & & \\
\hline fricative & $\mathrm{f}$ & $\mathrm{s}$ & $\mathrm{s}(\mathrm{sh})$ & $6(\mathrm{x})$ & $\mathrm{h}$ & \\
\hline nasal & $\mathrm{m}$ & $\mathrm{n}$ & & & $\mathrm{n}$ & \\
\hline liquid & & $\mathrm{l}$ & $\mathrm{r}$ & & & \\
\hline glide & $\mathrm{w}$ & & & $\mathrm{j}$ & & \\
\hline
\end{tabular}

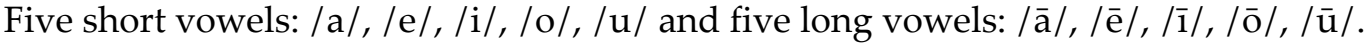

Affricates $t s, d z, t_{s}, d z$ occur mostly in Chinese and Tibetan loanwords.

In both languages stops and affricates are distinguished by aspiration; opposition of aspirated voiceless consonants vs. unaspirated voiceless consonants are often represented as opposition of strong vs weak consonants.

Mangghuer seems to be the only Mongolic language that has tones in native words. Dwyer (2008) discovered that several pairs of homophones differ in tones: one of the members of a pair is pronounced with a high tone, another with a low tone, e.g.

a. wulang [ $\left.{ }^{\mathrm{w}} \mathrm{u}^{22} \mathrm{a}^{55}\right]$ 'drinking'

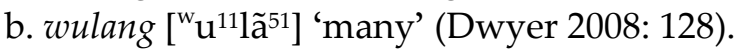

There are also some indications that Baoan is currently in the process of developing a tonal system (Li:1986), but so far these tones have been found in loanwords only, although they do not match the tones in the donor language.

In the following cases the same features can be observed in both Mangghuer and Mongghul, but in Mongghul they appear more systematically or more often:

- development of strong obstruents. If both the word-initial obstruent and the wordinternal obstruent are strong, the word-internal obstruent weakens, e.g. huja- 'to bark' $<{ }^{*} k u c a-$ (Georg 2003: 291). The sequence of initial weak obstruent + internal strong obstruent changes to initial strong obstruent + internal weak obstruent, e.g. pujig 'book' < *bicig (Georg 2003: 291). Weakening of the internal obstruent can also cause the appearance of secondary initial $h$-, e.g. Mangghuer $f_{3} u \sim s z u<{ }^{*} h u s u n<* u s u n$ 'water' (Nugteren 2011: 38), Halchighol xaldan (Todaeva 1973: 372), Naringhol xardam (SM 1933: 160) < *altan 'gold' (for details see Khelimsky 1984: 27; Georg 2003: 291-292; Nugteren 2011: 38, 252; Faehndrich 2007: 42-43). Such developments can be observed in all Mongolic languages of the region; in Monguor they are more frequent and systematical, and in Mongghul they appear more systematically than in Mangghuer;

- elision of vowels is also typical of Qinghai-Gansu languages, but it seems to appear more frequently in Mongghul, Baoan and SY. In many cases it leads to the appearance of new consonant clusters, including word-initial ones. Consonant clusters are found in all Mongolic languages of Qinghai-Gansu except for Dongxiang (but cf. Kim 2013: 351), whose syllabic structure has undergone strong Chinese influence. It is important to note that Mangghuer (for which we can compare historical records from the end of 
the $19^{\text {th }}$ century with modern data) has a tendency to eliminate secondary clusters via insertion of epenthetic vowels (Nugteren 2011: 91, 124-125, 127, 130-131, 133-134, 199). The precise number of such clusters differs: Georg lists 24 clusters in Halchighol (Georg 2003: 293). Faehndrich (2007: 73-74) notes that Karlong is in the process of developing new clusters (in addition to the 25 already attested clusters), which are not permitted in other Mongghul dialects. Junast and Li (1982: 478) state that Mongghul has twice as many clusters as Mangghuer, but they do not give the exact numbers. Anyway, Mongghul has many more initial clusters than Mangghuer.

The comparative data are given in Table 1.

There is a single phonetic shared innovation that separates Mangghuer and all Mongghul dialects from other Mongolic languages of Qinghai-Gansu: the reflex of ${ }^{*} k i-/{ }^{*} k i-$ (ći in Monguor and $k i / x i$ in the other languages, see Todaeva 1973: 30-31; Georg 2003: 291; Nugteren 2011: 219-220).

Phonetic variability within Mongghul dialects may be illustrated as follows:

- ${ }_{-}-l$ is retained as $-l$ in Halchighol and Karlong, but becomes $-r$ in Mangghuer and Naringhol. The same innovation can also be found in Kangjia, where final *-l has several reflexes: -Ø /-r/-l/-lV/-n (Sečenčogt 1999: 28; Nugteren 2011: 244);

- * $m$ remains as $-m$ in Naringhol and Halchighol, becomes $-n /-\eta$ in Mangghuer, and can be realized as $-m$ or $-n$ in Karlong. Mangghuer shares this innovation with Dongxiang and Kangjia. Sečenčogt (1999: 28) notes that in Kangjia * $m$ can also be realized as $-r$.

The Monguor idioms have one innovation in common with SY, namely a as a reflex of ${ }^{*} U$ in accented syllables (Nugteren 2011: 128).

The main phonetic differences between Mongolic languages of the region are presented below.

$-\mathrm{CM}^{*}-b$ - in intervocal position is retained as obstruent $-b$-, but turns to fricative $w, y$ or $\varnothing$ in the other languages (Nugteren 2011: 208-209);

- $C M^{*}-r b$ - remains as -rb-, but usually develops into - $r w$ - or $-r$ - in the other languages (for details see Nugteren 2011: 209);

- $C M^{*}-b C$ - is replaced by $-G$ - (usually before affricates and sibilants). In Mongghul it is either retained as $-b C$ - or changed into $s, s, s+C$; it is also retained in SY and Baoan, changes to fricative or affricate $+C /-r-+C$ in Kangiia, and is dropped in Dongxiang (for details see Nugteren 2011: 213);

- final $\mathrm{CM}^{*}$-r fuses with the preceding vowel into $x^{\sim}$ (Slater 2003a: 31) in Mangghuer, most probably under Chinese influence, but this change does not take place in Mongghul;

- $\mathrm{CM}{ }^{*}{ }^{\circ}$ and ${ }^{*} c$ develop into two sets (retroflexes and alveopalatals) in Mangghuer, but only into one set of affricates in other languages: alveopalatal in Mongghul and Baoan, palatal in SY and Kangjia and retroflexes in Dongxiang (Nugteren 2011: 218);

- velar ${ }^{*} k(a)$ is reflected as $q$ - in Mangghuer and Dongxiang but as $h$ - in Mongghul, Baoan and Kangjia; thus, Mongghul lacks aspirated uvulars. SY has both reflexes $q$ and $h$ - (Nugteren 2011: 220);

- $\mathrm{CM}^{*} h$ - before originally rounded vowels develops into $f$ - in Mongghul and Dongxiang in contrast with $h$ - in Mangghuer and SY. In Baoan and Kangjia both reflexes exist (for details see Nugteren 2011: 250);

- the vowel $i$ is realized as [1] and [1] following apicals and retroflexes in Mangghuer, Dongxiang and Kangjia under the influence of Chinese; 


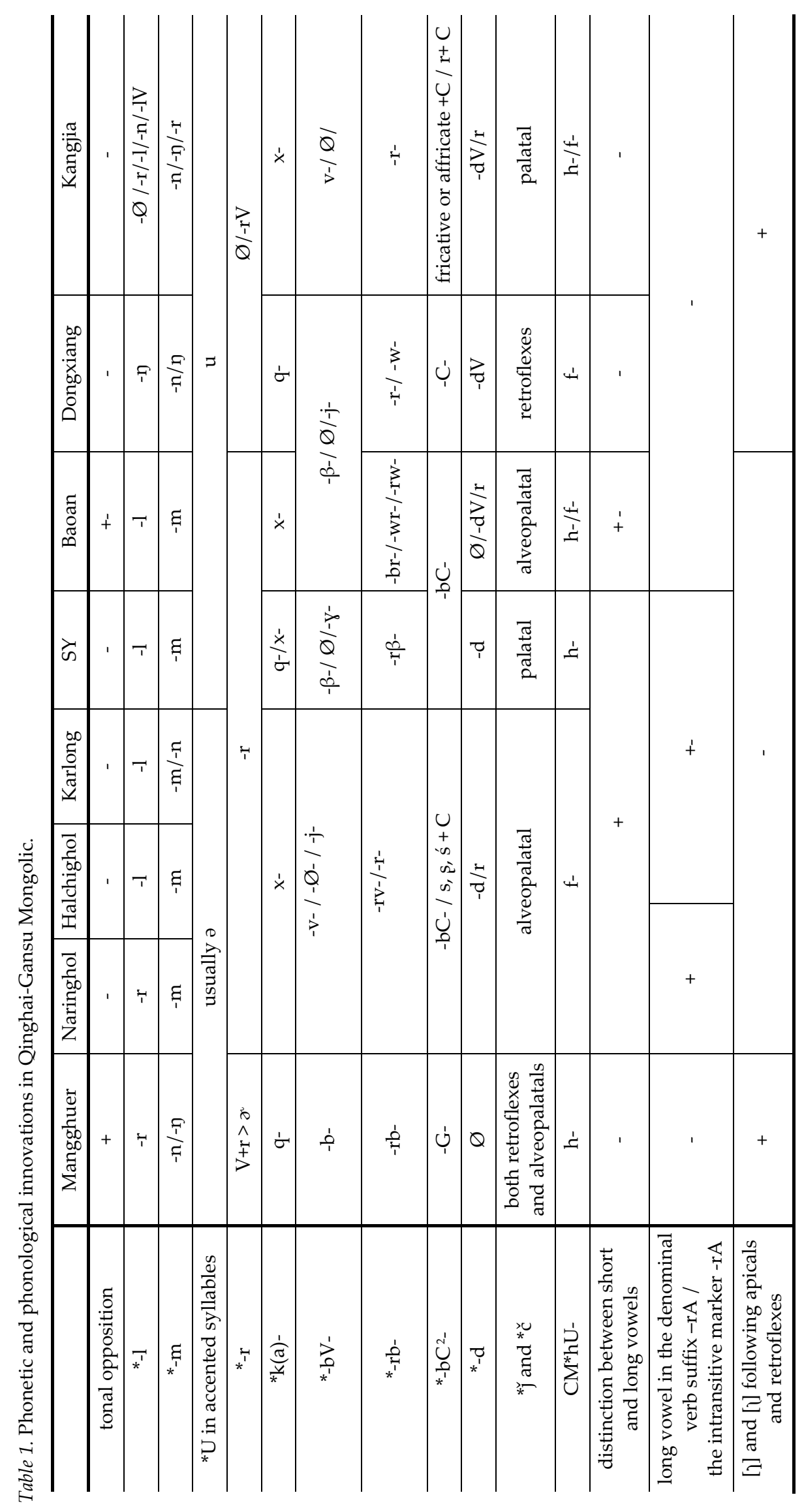

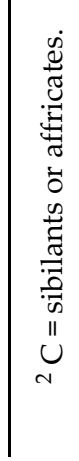


- secondary distinction of long and short vowels is present in Mongghul, Shira Yughur, Nantoq Baoan and Xiazhuang Baoan. Mangghuer, Dongxian, Dahejia Baoan and Kangjia lack it, although this loss might have been independent (and secondary as well); see details in Nugteren: 2011: 134-137. Chingeltei (1986) provides some examples of Mangghuer words with long vowels, but this phenomenon has not been confirmed in other grammatical manuals and descriptions;

- Nugteren (2011: 190-191) discusses the existence of vowel lengthening (or vowel length preservation) in Mongghul (and partly in SY) in the denominal verb suffix $-r A$ and the intransitive marker $-r A$.

\section{Word formation}

Borrowed Chinese or Tibetan verbs are adopted by attaching the following sets of suffixes:

- Mangghuer -la, -li (Slater 2003a: 113-114), Mongghul -la (Todaeva 1973: 95-96), Karlong -la (Faehndrich 2007: 130), SY -la (Tenishev, Todaeva 1966: 63) and Dongxiang -la, -lo, -lie (Todaeva 1961: 40), e.g. Halchighol gua (Chinese 挂 guà 'to hang') - guala (Todaeva 1973: 96).

- Mangghuer -ke, -ge (Slater 2003a: 113), Naringhol -ki, -gi, Halchighol -ki, -gi (Todaeva 1973: 95), Karlong -ki (Faehndrich 2007: 130-131), SY -ge (Tenishev, Todaeva 1966: 63), Baoan -ge (Todaeva 1973: 95), Dongxiang -gie (Kim 2013: 352). Todaeva (1973: 75) notes that in Halchighol and Naringhol the variant of the suffix depends on the type of initial consonant: laki 'to lead', but ta:gi 'to step'.

- Mangghuer -ra and Dongxiang -re -ro (Kim 2013: 352): Mangghuer gaoxinra "be happy'<Chinese gāoxìng 高兴 (Sater 2013: 113).

- Mangghuer tu: pintu 'be equal' < Chinese ping 平 'equal' (Slater 2013a: 113).

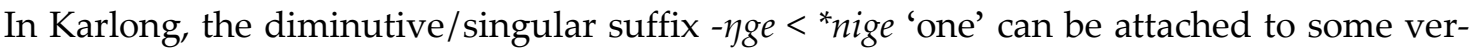
bal forms to weaken the strength of the statement (Faehndrich 2007: 183-184) or to underline a quick change of successive actions (Todaeva 1973: 129).

Only in Mangghuer can one find the comparative marker -her (Slater 2003b: 312).

Karlong uses a specific adjective intensifier -Gula (Faehndrich 2007: 84, 138).

Halchighol - mal and Naringhol -mar have preserved the Common Mongolic resultative marker (Georg 2003: 294), while other idioms have lost it.

Table 2. Word formation innovations in Qinghai-Gansu Mongolic

\begin{tabular}{|c|c|c|c|c|c|c|c|c|}
\hline & Mangghuer & Naringhol & Halchigol & Karlong & SY & Baoan & Dongxiang & Kangjia \\
\hline \multirow{4}{*}{$\begin{array}{l}\text { adaptation of } \\
\text { borrowed stems }\end{array}$} & la, li & la & la & la & la & & la, lie, lo & \\
\hline & ke, ge & gi & ki,gi & $\mathrm{ki}$ & ge & ge & gie & \\
\hline & ra & & & & & & re, ro & \\
\hline & tu & & & & & & & \\
\hline $\begin{array}{l}\text { singulative suffix } \\
\text { with verbs }\end{array}$ & & & & nge & & & & \\
\hline intensifier & & & & Gula & & & & \\
\hline comparative & her & & & & & & & \\
\hline resultative & & mar & mal & & & & & \\
\hline
\end{tabular}




\section{Noun}

Several Shirongolic languages (and Turkic Salar) have developed a postpositive indefinite article which goes back to Common Mongolic *nige- $n$ 'one', most probably due to Tibetan influ-

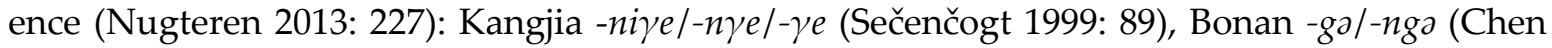
and Chingeltei 1986: 81), Mangghuer -ge/-gi (Todaeva 1973: 43) and Mongghul - $\eta g$ (Junast 1981a: 18), -nge/-ge (Todaeva 1973: 43; Faehndrich 2007: 84-86) (Table 3).

Cf. Kangjia:

ena kun nije so va

this person SG good be

'This person is good.' (Sečenčogt 1999: 90)

Table 3. Indefinite article in Qinghai-Gansu Mongolic.

\begin{tabular}{c|c|c|c|c|c|c|c}
\hline Mangghuer & Naringhol & Halchighol & Karlong & SY & Baoan & Dongxiang & Kangjia \\
\hline+ & + & + & + & - & + & - & + \\
\hline
\end{tabular}

The dualis marker -Gula/-Gurla in Karlong surprisingly does not correspond to the paucalis marker -Gula in Baoan, since the Karlong form goes back to Gu:r 'two' + la 'Instrumentalis' (Faehndrich 2007: 89), while Chen and Chingeltei convincingly argue that Baoan -Gula goes back to grammaticalization of Gulla 'three persons' < yurbarula (Chen \& Chingeltei 1986: 85-86, 159).

The pluralis marker -tang mentioned in (Chuluu 1994: 5) for Halchighol is not confirmed by any other source and, moreover, Faehndrich underlines that all her language consultants refused to accept this form as normal; consequently, we did not include it into the table.

The Halchighol / Karlong affix -mane/-mange is used for associative plurality only (Georg 2003: 295, Faehndrich 2007: 88).

Data on dualis and plural markers are presented in Table 4.

Table 4. Dualis and plural markers in Qinghai-Gansu Mongolic

\begin{tabular}{|c|c|c|c|c|c|c|c|c|}
\hline & Mangghuer & Naringhol & Halchighol & Karlong & SY & Baoan & Dongxiang & Kangjia \\
\hline Dualis & & & & -Gula/-Gurla & & & & \\
\hline \multirow[t]{7}{*}{ Pluralis } & & -sGi & -sge & -sgï & & & & \\
\hline & -se & & & -sï & $-s$ & & & -sun/-suu \\
\hline & & & -ngula & -ngula & & & & \\
\hline & & & $-n g u$ & -ngu & & & & \\
\hline & & & & -la & & -la & -la & $-1 a$ \\
\hline & & & & -sïla & & & $\begin{array}{c}\text {-si-la/-si-la/ } \\
\text {-s-la }\end{array}$ & -la-sun \\
\hline & $-\tan$ & $-\tan$ & & & & & $-\tan$ & \\
\hline $\begin{array}{l}\text { Associative } \\
\text { plurality }\end{array}$ & & & -mane & -mange & & & & \\
\hline
\end{tabular}

Case

An important feature of historical Mongolic morphonology is the reflexation of - $n$-stem declension. Unstable $-n$ gets lost in NOM in Mangghuer and Mongghul, but is preserved in SY 
and (not consistently) in Baoan, Dongxian and Kangjia (for details see Todaeva 1973: 30-31, 47; Georg 2003: 291, 295-296; Nugteren 2011: 45-47; Rybatzki 2003: 375). However, while in other Shirongolic idioms forms with originally unstable $-n$ are lexicalized either in $-n$ form or in $-\varnothing$ form, in Mongghul $-n$ is absent in NOM, but occurs in DAT.LOC in Karlong, and in DAT.LOC and ABL in Halchighol and Naringhol (Faehndrich 2007: 100).

Merging of GEN and ACC in one affix across the nominal paradigm (but not in Pronominal declension, see below) is a common feature for all QG languages, and thus we did not include it into the table. However, it is worth mentioning that Faehndrich (2007: 110) lists variants -ni, $-n a$ and -na for Genitive in Tianzhu dialect, but only -ni and -na for Accusative.

There is a peculiar reflex of DAT.LOC *DU > di (Rybatzki 2003: 377). According to Rybatzki, it occurs only in Shira Yughur and Halchighol; however, it is also present in Karlong (Faehndrich 2007: 94).

Mongghul locative $-r V$ corresponds to Dongxiang Prolative -ra (Faehndrich 2007: 110). The Tianzhu dialect of Mongghul demonstrates a longer form of the locative -tora, which possibly may imply that Todaeva (1973: 51-52) was right assuming that the locative $-r V$ in Mongghul might be a grammaticalized form of the locative adverbs dotu-ra 'inside' and de'e-re 'over' etc. However, it might as well be an archaism preserving the same locative marker that can easily be found in the aforementioned locative Mongolic adverbs and in dow-ra 'below' (Gruntov, Mazo 2020 forthcoming), and in that case Tianzhu form might be an instance of a compound affix (DAT.LOC + PROL).

Monguor languages have developed a new DIR marker (Naringhol - $d z i$, -dzidzi, Mangguer $\left.-d z_{i} i,-d z u d z i\right)$, which is a result of grammaticalization (Slater 2003: 171-172; Nugteren 2014).

Table 5. Case in Qinghai-Gansu Mongolic.

\begin{tabular}{|c|c|c|c|c|c|c|c|c|}
\hline & Mangghuer & Naringhol & Halchighol & Karlong & SY & Baoan & Dongxiang & Kangjia \\
\hline unstable $-n$ in Nom & - & - & - & - & + & +- & +- & +- \\
\hline DAT.LOC ${ }^{*}$ DU $>$ di & & & di & $\mathrm{di}$ & di & & & \\
\hline $\mathrm{LOC}-\mathrm{rV}$ & & -re & -ra/-re/-ri & $-r i$ & & & -rə (Prolative) & \\
\hline DIR & -dzil/-dzidzi & -dzil/-dzuži & - & - & - & - & - & - \\
\hline INS I SOC & $-1 a$ & -la/-ra & $-1 a$ & $-1 a$ & $-1 \mathrm{~V}$ & -Galə & -lə / -Gala & -Gala \\
\hline $\mathrm{COM}$ & -tai & -dē & $-\mathrm{de} /-\mathrm{d} \overline{1}$ & - & $-\mathrm{di}$ & - & - & - \\
\hline
\end{tabular}

\section{Personal and impersonal possession}

Loss of $1^{\text {st }}$ and $2^{\text {nd }}$-person possessive affixes in Monguor languages, Baoan and Kangjia seems to be an areal innovation (Rybatzki 2003: 380).

Reflexive (impersonal possessive particle) in QG languages goes back to the Common Mongolic reflexive particle ${ }^{*}$ ben.

Table 6. Possessive affixes in Qinghai-Gansu Mongolic

\begin{tabular}{l|c|c|c|c|c|c|c|c}
\hline & Mangghuer & Naringhol & Halchighol & Karlong & SY & Baoan & Dongxiang & Kangjia \\
\hline Reflexive particle & na / nang & nā & nā & na/ nā & -an & - & ne & - \\
\hline $\begin{array}{l}1^{\text {st }} \text { and 2nd Person } \\
\text { possessive affixes }\end{array}$ & - & - & - & - & + & - & + & - \\
\hline
\end{tabular}

${ }^{3}$ Long vowel variant is attested in Faendrich 2007: 124. 


\section{Pronouns}

The most striking feature of pronominal declension is a tendency to merge ACC and DAT.LOC forms. This merger for $1^{\text {st }}$ and $2^{\text {nd }}$ person sg. pronouns (and partly for plural pronouns) is fully completed in Baoan. In Mongghul $1^{\text {st }}$ person sg. pronoun fuses DAT.LOC and ACC forms across all varieties of the language; however, the $2^{\text {nd }}$ person sg. merges ACC and DAT.LOC only in Naringhol and Tianzhu Mongghul. Mangghuer (despite Rybatzki 2003: 376) has different variants of singular pronouns, except for the $2^{\text {nd }}$ sg., where the DAT.LOC enclitic $-d u$ might be optional (Slater 2003a: 83).

Table 7. ACC and DAT.LOC forms of $1^{\text {st }}$ and $2^{\text {nd }}$ person pronouns in Mangghuer, Mongghul and Baoan (Todaeva 1973: 72; Slater 2003a: 83; Chen and Chingeltei 1986: 390, 176; Faehndrich 2007: 118)

\begin{tabular}{|c|c|c|c|c|c|c|}
\hline & \multicolumn{2}{|c|}{ Mangghuer } & \multicolumn{2}{|c|}{ Mongghul } & \multicolumn{2}{|c|}{ Baoan } \\
\hline & $1 \mathrm{Sg}$ & $2 \mathrm{Sg}$ & $1 \mathrm{Sg}$ & $2 S g$ & $1 S g$ & $2 \mathrm{Sg}$ \\
\hline ACC & $\begin{array}{c}\text { namei, nangda, } \\
\text { nami, dami, } \\
\text { damei, dangda }\end{array}$ & $\begin{array}{c}\text { čimi } \\
\text { (Todaeva), } \\
\text { qimei (Slater) }\end{array}$ & \multirow{2}{*}{$\begin{array}{c}\text { ndā } \\
\text { (Halchighol, } \\
\text { Karlong, } \\
\text { Naringhol), } \\
\text { dā (Tianzhu) }\end{array}$} & $\begin{array}{l}\text { čimu (Halchighol) } \\
\text { qimu (Karlong) } \\
\text { čimī (Naringhol) } \\
\text { qimī (Tianzhu) }\end{array}$ & \multirow{2}{*}{$\begin{array}{c}\text { mənda, } \\
\text { məndə, nada, } \\
\text { nadə }\end{array}$} & \multirow{2}{*}{$\begin{array}{l}\text { qinda, qada, } \\
\text { qeda, qedə }\end{array}$} \\
\hline DAT.LOC & $\begin{array}{c}\text { nameidu, } \\
\text { namidu, } \\
\text { damidu, } \\
\text { nangda(du) }\end{array}$ & $\begin{array}{l}\text { čimidu } \\
\text { (Todaeva) } \\
\text { qimei(du) } \\
\text { (Slater) }\end{array}$ & & $\begin{array}{l}\text { qimi (Karlong) } \\
\text { čimī (Halchighol, } \\
\text { Naringhol), } \\
\text { qimī (Tianzhu) }\end{array}$ & & \\
\hline
\end{tabular}

Loc. in -re for the $1^{\text {st }}$ personal pronoun (munire) was recorded only in Naringhol by de Smedt and Mostaert (Todaeva 1973: 70), but is absent in other Mongghul varieties and Mangghuer.

\section{Verbs}

Common Mongolic had markers for reciprocal voice ${ }^{*}-(V) l d V$ - and for cooperative voice *-(V)ľca- (cf. Janhunen 2003: 11). In modern QG languages their reflexes are often confused. In Mangghuer, Halchighol, Naringhol, Karlong, Kangiia, Dongxiang, and Shira Yughur reflexes of the reciprocal voice function as both voices. In Baoan, on the contrary, the reflex of the cooperative voice marker -či has acquired the functions of both voices (Todaeva 1964: 74). Descriptions of Tianzhu Mongghul lack the reciprocal or cooperative voice (Faehndrich 2007: 189).

Table 8. Merger of Reciprocal \& Cooperative voices in Qinghai-Gansu Mongolic (Todaeva 1973: 102-103; Faendrich 2007: 189; Tenishev, Todaeva 1966: 65; Todaeva 1961: 42; Sečenčogt 1999: 135)

\begin{tabular}{l|c|c|c|c|c|c|c|c}
\hline & Mangghuer & Naringhol & Halchighol & Karlong & SY & Baoan & Dongxiang & Kangjia \\
\hline $\begin{array}{l}\text { Merger of } \\
\text { Reciprocal \& } \\
\text { Cooperative voices }\end{array}$ & -rde & -rdi/-di & -lde/-de & -ldi & -lda/-lde & -či & -ndu & -ndu/-du \\
\hline
\end{tabular}


Imperative forms

Of all the forms of imperative in QG languages it is the desiderative marker which demonstrates the greatest diversity.

The origin of the formant lax-/laš- in Mangghuer and Mongghul (Faehndrich 2007: 156, 185; Todaeva 1973: 105) is unclear. Slater does not mention -lašgi in his description (Slater 2003a: 117), but Todaeva cites examples with both affixes. Thus, this element might be an innovation at the Proto-Monguoric level, since it is not attested in other QG languages.

For their equational constructions Mangghuer and Dongxian have borrowed the Chinese copula (是 shi) (Slater 2003a: 238; Todaeva 1961: 143) which does not have any inflectional variants (Slater 2003b: 318).

Table 9. Distribution of the desiderative marker and the copula shi in Qinghai-Gansu languages.

\begin{tabular}{l|c|c|c|c|c|c|c|c}
\hline & Mangghuer & Naringhol & Halchighol & Karlong & SY & Baoan & Dongxiang & Kangjia \\
\hline Desiderative 3Sg & -gi, -lašgi & -ragi & -ge, -laxge & -laxgi & -gene, -yane & -gə & -gə & -gu \\
\hline Chinese copula shi & + & & & & & & + & + \\
\hline
\end{tabular}

Tense / aspect forms

Many languages of the Amdo Sprachbund, including most Mongolic languages of the region, have developed the category of perspective (subjective/objective distinction), i.e. marking of speaker involvement into the action, which strongly correlates with controlled vs. noncontrolled actions. They have adopted this category from Tibeto-Burmanese languages (cf. detailed analysis in Slater 2003a: 194-218; Slater 2018; Brosig and Skribnik 2018: 575-579). Thus, the whole system of Common Mongolic tense/aspect affixes in most QG languages (except Dongxiang) was drastically restructured in order to fit into this new category. In some cases new affixes originated from converb/participle + copula constructions (e.g. Mangghuer $-n i<$ modal converb $-n+$ copula); in other cases old affixes acquired new functions (e.g. Past tense affix - $b a$ in Mangghuer became a Subjective past affix).

In Shira Yughur the prospective category is clearly seen in Past tense. Nugteren (2003: 279-280) describes it as a $1^{\text {st }}$ vs $2^{\text {nd }}-3^{\text {rd }}$ person opposition, but actually it is most probably the same phenomenon as perspective. It is worth noting that Todaeva also initially considered the opposition of subjective vs prospective in Monguor and Baoan as a sign of emerging personal conjugation and opposition of $1^{\text {st }}$ vs $2^{\text {nd }} \& 3^{\text {rd }}$ person (Todaeva 1973: 110-115; Todaeva 1964: 89 ), although she already proposed the possible influence of corresponding Tibetan copular construction on this phenomenon (Todaeva 1964: 89).

The present tense in Shira Yughur can also indicate similar processes. There are two present tenses: $-n A i$, which is described as referring to involuntary mental and physical actions, vs -jla wai -dla wai referring to "specific concrete actions which are being consciously performed in the present" (Nugteren 2003: 279). It is clear that the second form goes back to the combination of imperfective converb -ji with the copula, a combination generally used in Mongolic for progressive aspect, hence the meaning "concrete actions". However, the opposition of voluntary and involuntary actions exactly matches the opposition of non-volitional, out of control objective forms vs. volitional controlled subjective forms in Mangghuer, described in detail by Slater in (2003a: 194-220).

Mangghuer Objective Future affix -kun(i)ang (Slater 2003b: 316) obviously goes back to a combination of future participle with the copula. Interestingly, Todaeva (1973: 119) explicitly 
states that her Minhe Mangghuer materials do not contain any examples of such combinations.

Mongghul future affix $-m$ in Karlong refers to both future and present situations (Faehndrich 2007: 156-157).

Mangghuer present forms might be the only reflex of CM confirmative tense *-lara in QG languages.

In Table 10 below we present the system of tense and aspect forms in QG languages. The data are drawn from the following sources: Slater 2003a, 2003b for Mangghuer; Faehndrich 2007 for Karlong and Naringhol; Todaeva 1973 for Halchighol and Naringhol; Junast 1981 and Georg 2003 for Halchighol; Tenishev, Todaeva 1966, Nugteren 2003, and Bulchulu and Jalsan 1990 for Shira Yughur; Todaeva 1964, Chen and Chingeltei 1986, and Wu Hugjiltu 2003 for Baoan; Todaeva 1961, Buhe et al. 1985, and Kim 2003 for Dongxiang; Sečenčogt 1999, 2002 for Kangjia.

Negation and prohibitive particles

General distribution of prepositive indicative negation particles demonstrates reflexes of Common Mongolic negation particle *ülü for non-past verb forms and reflexes of *ese for past forms. However, this distribution can vary. The particle $\bar{\imath}$ in Naringhol and Karlong may be an irregular variant of $* \ddot{u} l \ddot{u}>$ lie $>\bar{\imath}$. In Halchighol $l \bar{\imath}$ is used with present and future, rarely with past. The particle se is used exclusively before the past form (Todaeva 1973: 136). In Naringhol $\bar{\imath}$ occurs rarely (Todaeva 1973: 136), Georg transcribes this marker as yii (Georg 2003: 303); aside from that, descriptions of Naringhol also mention the particles li (SM 1933: 222) and se (SM 1933: 341). Karlong $l \bar{l}$ is used with finite verbs, $\bar{\imath}$ with finite and non-finite verbs (Faehndrich 2007: 217-219). Reflexes of *ese are not attested in Karlong. Mangghuer lai is typically placed before imperfective verbs, sai before perfective ones (Slater 2003a: 146-147). Baoan (Todaeva 1964: 107), Dongxiang (Kim 2003: 362), and Kangjia (Sečenčogt 1999: 202-203) preserve the basic distribution. SY has only li l' (< *ülü) (Nugteren 2003: 283).

For Mangghuer Todaeva (1973: 107) gives $b u$ as a prohibitive particle, but Slater (2003a: 147-148) instead transcribes the prohibitive as bao and states that in folktales there are two rare alternative forms bai and $b u$, the latter probably a Chinese loanword. Mongghul data are taken from (Todaeva 1973:107; Faehndrich 2007: 218-219). Dongxiang bu (Todaeva 1961: 58) and Baoan sGo.dmar dialect ba (Chen and Chingeltei 1986: 302) go back to CM *bu, but reflexes of CM prohibitive particle *bitügei were preserved only in Baoan təga (Chen and Chingeltei 1986: 302), SY püti (Nugteren 2003: 283) and Kangjia bude (Sečenčogt 1999: 139-140).

Table 11. Negation and prohibitive particles in Qinghai-Gansu Mongolic

\begin{tabular}{|c|c|c|c|c|c|c|c|c|}
\hline & Mangghuer & Naringhol & Halchighol & Karlong & SY & Baoan & Dongxiang & Kangjia \\
\hline Negation particles & lai/sai & $\begin{array}{c}\overline{1}(\mathrm{y} \overline{1}) ? / \\
\mathrm{li} / \mathrm{se}\end{array}$ & lì/se & lī/i & li l' & lə/sə & ulie/ese & ne/se \\
\hline $\begin{array}{l}\text { Prohibitive particle } \\
<\mathrm{CM} \text { *bü }\end{array}$ & bu, bao & $\mathrm{b} \overline{\mathbf{1}}$ & $\mathrm{b} \overline{1}$ & $\mathrm{~b} \overline{1}$ & & (bə) & bu & \\
\hline $\begin{array}{l}\text { Prohibitive particle } \\
<C M \text { *bitügei }\end{array}$ & & & & & püti & təgə & & bude \\
\hline
\end{tabular}




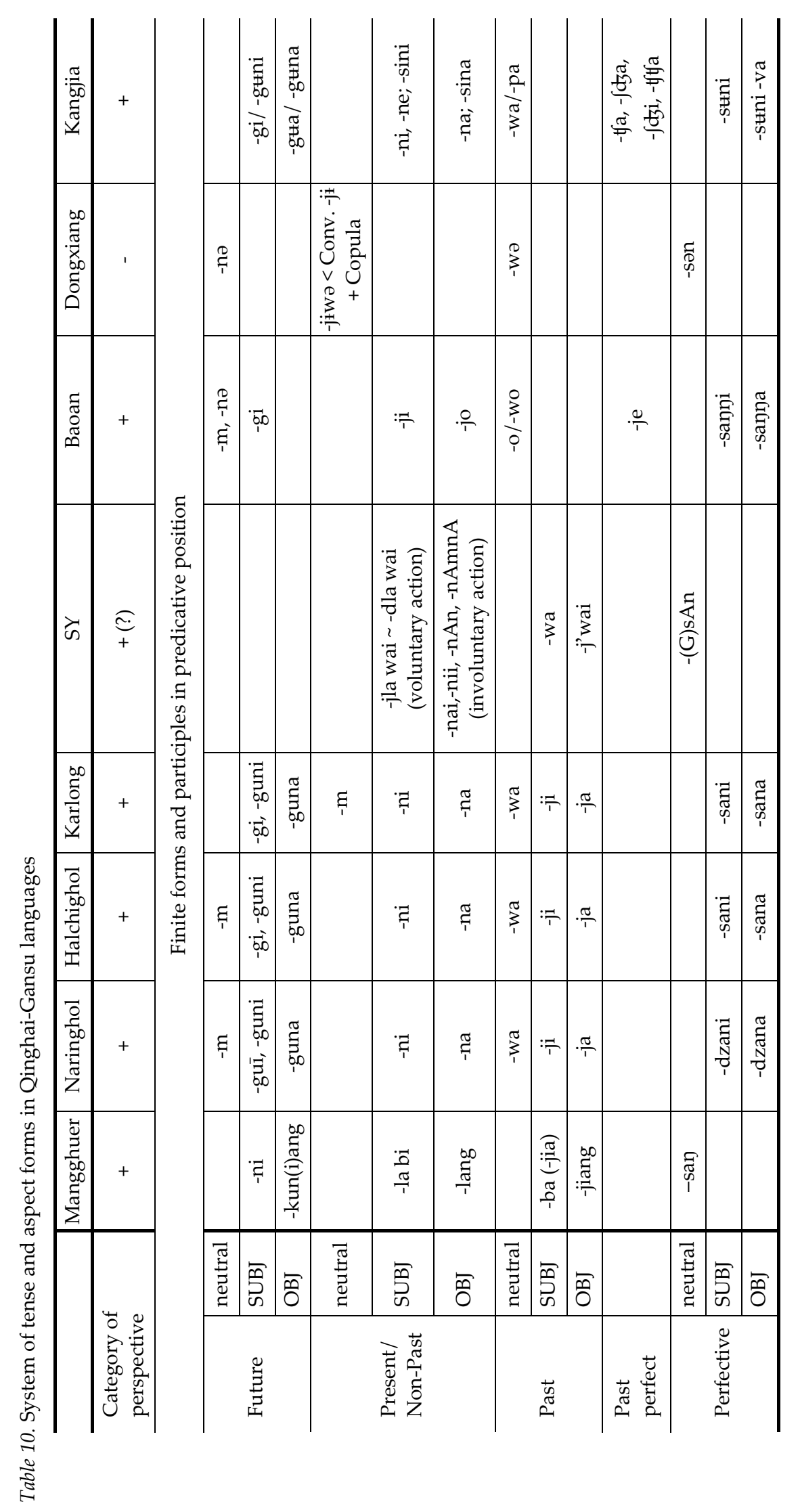




\section{Converbs}

Imperfective converb

Mongghul (all dialects) -ji, Mangghuer -ji (Todaeva 1973: 123-124), Dongxiang -ji (Todaeva 1961: 49), Baoan -ji (Todaeva 1964: 95), SY -ji/-ci (Nugteren 2003: 276), Kangjia -jj/-dsi (Sečenčogt 1999: 163). Since all the forms are similar, we do not include them into the table. However, it is interesting that at least in Dongxiang, Shira Yughur, and Kangjia this converb can be used as a reduplicative form (Todaeva 1961: 49; Sečenčogt 1999: 163; Nugteren 2003: 276). Cf., e.g., Dongxiang hela xoluji xoluji. 'They run and run...' (Todaeva 1961: 49).

\section{Perfective converb}

In QG languages reflexes of two different Common Mongolic forms ${ }^{*} \gamma a$ and ${ }^{*} \gamma a d$ are used in the function of a perfective converb.

In Mongghul dialects there are different perfective converbs: Halchighol: $-\bar{a}(-\bar{e},-\bar{o}),-\bar{a} n u$ $(-\bar{e} n u,-\bar{o} n u),-w \bar{a},-w \bar{a} n u$, Naringhol: $-w \bar{a},-w \bar{a} n u /-j \bar{a},-j \bar{a} n u$, Karlong: $-\bar{a},-\bar{e} d$ (Todaeva 1973: 124-

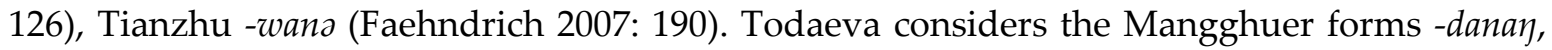
-daGanay, -daGali as converb markers, while Slater treats danang as a separate word (the conjunction 'after') and quotes the form - $d a$ with the same meaning (Slater 2003a: 263-266). Baoan has no such form (Todaeva 1973: 127), while Dongxiang forms -do, -dono (Todaeva 1961:49) are cognates of Mangghuer ones. Kim (2003: 360) calls these Dongxiang forms quasiconverbs. SY forms $-\bar{a},-\bar{e},-\bar{a} d,-\bar{e} d$ (Tenishev, Todaeva 1966: 71), -Gādu, $-\bar{a} d u$ (Bulchulu and Jalsan 1990: 278279; Nugteren 2003: 277) obviously correspond to those in Karlong. Kangjia has -da, -dzida (Sečenčogt 1999: 154). Closely related might be such special forms as Karlong -di, Tianzhu -di (Faehndrich 2007: 180-181), which Faehndrich calls “completive”.

Modal converb

Mangghuer $-n$, Mongghul $-n$ (in Karlong one can also add the singular marker to this converb:

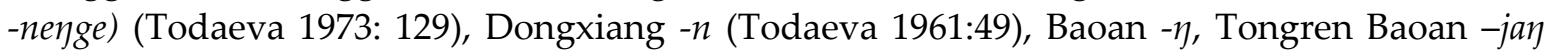
(Todaeva 1964: 95). In SY the modal converb $-(V) n$ usually occurs in reduplicative sequences indicating a "repeated action performed during the action of the main verb, e.g. ci muni zaghalidi xalda-n xalda-n üleyaan bar “do your work while looking at my portrait!" (Nugteren 2003: 276). Rybatzki (2003: 382) states that Mangghuer has lost this participle, judging by the absence of this converb in Slater's description (Slater 2003b: 315); however, Todaeva (1973: 129) gives undoubtable examples of the existence of this converb in Mangghuer: Te gerdu oron tengiji saGaba 'Entering (converbum modale) the house he asked in such a way...'.

Consecutive converb

Monghhul -gulā, Mangghuer -kula (Todaeva 1973: 130), Kangjia -gzt,-głma и -gzda (Sečenčogt 1999: 162), Baoan -gutłi, -guma (Chen and Chingeltei 1986: 222-223). Xiazhuang Baoan and Dadun Baoan also have -taxay (Chen and Chingeltei 1986: 222-223; Todaeva 1964: 95). Dongxiang and Shira Yughur lack this converb. In Karlong there is a single example in Faehndrich's data (Faehndrich 2007: 168).

Conditional converb

The conditional converb is present everywhere in QG languages and its affixes differ only phonetically. Halchighol -sa, Karlong -sa, Naringhol - $d z a$, Mangghuer -sa (Todaeva 1973: 131132), Dongxiang -sa (Todaeva 1961: 60), Baoan -sa (Xiazhuang, Dadun -sa; Ganhetan -s)) (Chen and Chingeltei 1986: 223-224), SY -sa, -se (Tenishev, Todaeva 1966: 71), Kangjia -sa (Sečenčogt 
1999: 157-159). We do not include it into the table, but list these forms here, since they help to understand how the concessive converb is constructed.

Concessive converb

In QG languages the concessive converb can be formed on the basis of the conditional converb *-sA with additional affixes. Mongghul -sada (Todaeva 1973: 132), Shira Yughur -sada (Nugteren 2003: 277), Kangjia -sala (Sečenčogt 1999: 159-161), Dongxiang -seda (Todaeva 1961: 51), but -se-nu in (Kim 2003: 360), and Baoan -sede (Todaeva 1964: 97). According to Todaeva, Dongxiang $-s e-n u$ is functionally synonymous with the perfective converb, while according to Kim, -se-nu basically serves as a concessive converb, but sometimes can also be used in the meaning 'after' (Todaeva 1961: 51; Kim 2003: 360). In Mangghuer concessive functions are performed by conditional converb -sa (Slater 2003a: 255-256).

Terminative converb

The terminative converb is also present in all QG languages, but the variation is interesting. For Mongghul Todaeva gives Halchighol -delā, Naringhol -delāa-derā, Fulaan nura (= Karlong)

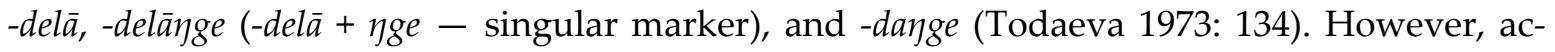
cording to Faehndrich, Karlong -delā is not accepted by speakers (Faehndrich 2007: 190), and she gives the form -tala instead (Faehndrich 2007: 170-171). Mangghuer -tula/-tala (Slater 2003a: 254-255), Baoan -tala, -talo, -tala, -dala (gNyan.thog Baoan -tala has variants -sala, -la, Xiazhuang Baoan has -salo) (Chen and Chingeltei 1986: 226-227), Dongxiang -tala (Todaeva 1961: 51), SY -tAlA (Tenishev, Todaeva 1966: 71), Kangjia -tala (Sečenčogt 1999: 161). Actually, Baoan

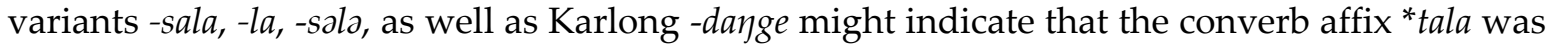
originally a composite affix, and in descendant languages we witness the reflection of some old composite variants.

Abtemporal converb

Halchighol -sār, Mangghuer -sar (Todaeva 1973: 134), Mangghuer -ser (Slater 2003b: 315). According to Faehndrich, (2007: 190) -sār is not accepted by the speakers of Karlong, and $-n$ with reduplication is used instead. SY has $-s \bar{a} r /-g s \bar{a} r$ (Bulchulu and Jalsan 1990: 282-283). Todaeva shows that Qinghai Baoan -ser is used without any restrictions (Todaeva 1964: 95), but Chen and Chingeltei (1986: 230-231) report that -sar is used only in Gansu Baoan and Xiazhuang subdialect of Qinghai Baoan exclusively within the construction -sar + verb su- 'live, sit' (Chen and Chingeltei 1986: 230-231). This form is absent in Dongxiang and Kangjia.

Zero-marked converb

Rybatzki mentions a zero-marked serial converb as an important innovation confined to Gansu-Qinghai "attested at least in Shira Yughur, Mangghuer, Bonan, and Santa" (Rybatzki 2003: 383). Todaeva (1973: 127-128) also cites Mongghul examples, and Sečenčogt gives examples from Kangjia (Sečenčogt 1999: 164). Thus, this isogloss is valid for all QG languages.

\section{Numerals}

There are several patterns for deriving ordinal numbers from numeral stems: prefixes (Baoan ay-, ayga- from Tibetan, see Chen and Chingeltei 1986: 157-158; Mangghuer di-, see Todaeva 1973: 91, Dongxiang క̌i-, see Todaeva 1961: 36-37, Kangjia క̌i-, di-, see Sečenčogt 2002: 69; all three from Chinese 第 $d i$-), or affixes (Mongghul -dar, see Todaeva 1973: 91, Dongxiang -da, see Todaeva 1961: 36-37 < Common Mongolic *-duyar; SY -cAAr or -rjAr, see Nugteren 2003: 271272 of unclear origin). 


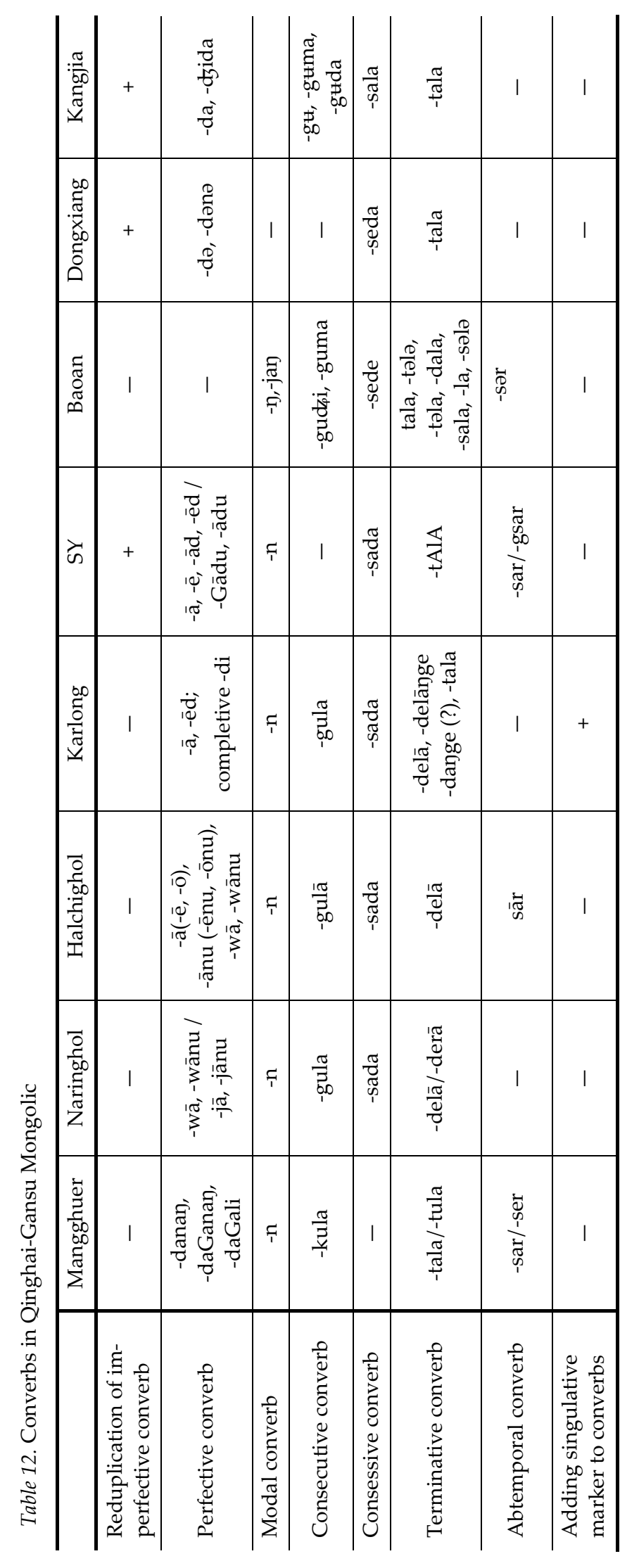


Several Qinghai-Gansu languages have borrowed Chinese numeral classifiers (Slater 2003a: 95-96; Faehndrich 2007: 135-136; Sečenčogt 2002: 70).

Table 13. Qinghai-Gansu innovations in numerals

\begin{tabular}{|c|c|c|c|c|c|c|c|c|}
\hline & Mangghuer & Naringhol & Halchighol & Karlong & SY & Baoan & Dongxiang & Kangjia \\
\hline $\begin{array}{l}\text { Numeral prefixes } \\
\text { (ordinal numbers) }\end{array}$ & di- & -dar & -dar & -dar & $\begin{array}{c}\text {-cAAr / - } \\
\text { rjAr }\end{array}$ & $\begin{array}{l}\text { an-, } \\
\text { ange- }\end{array}$ & $\begin{array}{l}\breve{3} \mathrm{i}- \\
-\mathrm{da}\end{array}$ & $3 ̌ i-$ \\
\hline Numeral classifiers & + & & & + & & & + & + \\
\hline
\end{tabular}

\section{Syntactic patterns}

Causee marking in causative constructions varies: Halchighol uses ACC (for originally intransitive stems) and DAT.LOC (for originally transitive stems) (Todaeva 1973: 100-101); Karlong allows only Accusative in both cases (Faehndrich 2007: 182). In Naringhol the data are scarce, but there are at least examples of DAT.LOC marking for the causee (SM 1964: 20).

Mangghuer, according to Todaeva's records (Todaeva 1973: 100-101), only marks causee with ACC, and she underlines that this feature differentiates Huzhu Mongghul from Minhe Mangghuer, but Slater states that in Mangghuer causee receives accusative (for originally intransitive verbs) and dative (for originally transitive verbs) (Slater 2003a: 130). Kangjia (Sečenčogt 1999: 134), Dongxiang (Todaeva 1961: 41-42) and Baoan (Todaeva 1964: 72-73) also allow both dative and accusative marking. Shira Yughur demonstrates an alternative strategy with INS and DAT.LOC cases (Tenishev, Todaeva 1966: 64), which is more similar to Central Mongolic systems (see e.g. ACC, DAT.LOC and INS in Written Mongolian, Khalkha and Buriad, ACC and INS in Kalmyk).

Table 14. Causee marking in Qinghai-Gansu Mongolic

\begin{tabular}{l|c|c|c|c|c|c|c|c}
\hline & Mangghuer & Naringhol & Halchighol & Karlong & SY & Baoan & Dongxiang & Kangjia \\
\hline $\begin{array}{l}\text { Causee } \\
\text { marking }\end{array}$ & ACC/ & ACC (?)/ & ACC/ & ACC & DAT.LOC/ & ACC/ & ACC/ & ACC/ \\
DANS & DAT.LOC & DAT.LOC & DAT.LOC & DAT.LOC & DAT.LOC \\
\hline
\end{tabular}

\section{Lexicon}

A comparative analysis of the lexicon of QG languages, focusing on the percentage of borrowed and Common Mongolic etyma, is provided in Rybatzki (2003: 385-386). In this work V. Rybatzki claims that Mangghuer has only 39\% of the native lexicon and thus "it is obvious that Mangghuer has suffered a massive loss of native vocabulary, making it, at least lexically, a good candidate for a 'mixed language'". Bonan (=Baoan) in his data demonstrates $50 \%$ of native vocabulary, Santa (i.e. Dongxian) has 56\%, Monggul has 72\%, and Shira Yughur has 77\%.

Hattori (1959) and Kuzmenkov (1993) in their glottohronological studies on Mongolic lexicon considered Monguor to be a single idiom and did not use data from any other QG languages.

In our previous analysis (Gruntov, Mazo 2015) we scrutinized data for 110 basic lexical items from all Mongolic languages. It turned out that Mangghuer has $98 \%$ of common lexicon with Mongghul. Later we also analyzed the Leipzig-Jakarta list of 250 basic words for QG lan- 
guages (unpublished) and found that $81 \%$ of the lexicon (76\% if we eliminate all the borrowings) are still in common for Mangghuer and Mongghul. Thus, Mangghuer is lexically closer to Mongghul than to any other language, which is not surprising.

\section{Shared innovations}

We can summarize the previous data in the following table, showing the unique and shared innovations of Mangghuer, Halchighol, Naringhol and Karlong compared to other QG languages.

Table 15. Monguor innovations in Qinghai-Gansu languages

\begin{tabular}{|c|c|c|c|c|}
\hline № & Innovation & Languages & $\begin{array}{l}\text { Number of } \\
\text { languages }\end{array}$ & Comment \\
\hline 1 & $-k V$ for the borrowed stems & Mgr, MN, MH, MK, SY, B, D & 7 & \\
\hline 2 & $\begin{array}{l}\text { reflex of Reciproc functions as both } \\
\text { Reciproc and Cooperative voices }\end{array}$ & Mgr, MN, MH, MK, SY, D, K & 7 & \\
\hline 3 & perspective & Mgr, MN, MH, MK, SY, B, K & 7 & \\
\hline 4 & initial clusters allowed & Mgr, MN, MH, MK, SY, B, K & 7 & \\
\hline 5 & $* b>v$ & $\mathrm{MN}, \mathrm{MH}, \mathrm{MK}, \mathrm{SY}, \mathrm{B}, \mathrm{D}, \mathrm{K}$ & 7 & \\
\hline 6 & $-l V$ for the borrowed stems & Mgr, MN, MH, MK, SY, D & 6 & \\
\hline 7 & loss of resultative & Mgr, MK, SY, B, D, K & 6 & \\
\hline 8 & indefinite article & Mgr, MN, MH, MK, B, K & 6 & \\
\hline 9 & causee ACC/DAT.LOC & Mgr, MN, MH, B, D, K & 6 & \\
\hline 10 & loss of $1^{\text {st }}$ and $2^{\text {nd }}$ poss.affixes & Mgr, MN, MH, MK, B, K & 6 & \\
\hline 11 & $* q>x$ & $\mathrm{MN}, \mathrm{MH}, \mathrm{MK}, \mathrm{SY}, \mathrm{B}, \mathrm{K}$ & 6 & \\
\hline 12 & $* h U>f$ & $\mathrm{MN}, \mathrm{MH}, \mathrm{MK}, \mathrm{B}, \mathrm{D}, \mathrm{K}$ & 6 & \\
\hline 13 & concessive converb -sVdV & MN, MH, MK, SY, B, D & 6 & \\
\hline 14 & ${ }^{*} U>a$ in accented syllables & Mgr, MN, MH, MK, SY & 5 & \\
\hline 15 & loss of prohibitive particle *bitügei & Mgr, MN, MH, MK, D & 5 & \\
\hline 16 & ${ }^{*}-r b->-r-$ & $\mathrm{MN}, \mathrm{MH}, \mathrm{MK}, \mathrm{D}, \mathrm{K}$ & 5 & \\
\hline 17 & $*-d>r$ & $\mathrm{MN}, \mathrm{MH}, \mathrm{MK}, \mathrm{B}, \mathrm{K}$ & 5 & \\
\hline 18 & secondary long vowels & MN, MH, MK, SY, B & 5 & \\
\hline 19 & $*-m>-N$ & Mgr, MK, D, K & 4 & \\
\hline 20 & loss of unstable $-n$ in Nom & Mgr, MN, MH, MK & 4 & \\
\hline 21 & desiderative $-l a C g i$ & Mgr, MN, MH, MK & 4 & \\
\hline 22 & adtemporal $-s V r$ & Mgr, MH, SY, B & 4 & \\
\hline 23 & numeral classifiers & Mgr, MK, D, K & 4 & \\
\hline 24 & LOC $-r V$ & $\mathrm{MN}, \mathrm{MH}, \mathrm{MK}, \mathrm{D}$ & 4 & \\
\hline 25 & merge of ACC/DAT $1 S g$ & $\mathrm{MN}, \mathrm{MH}, \mathrm{MK}, \mathrm{B}$ & 4 & \\
\hline 26 & perfective converb in $-V V$ & $\mathrm{MN}, \mathrm{MH}, \mathrm{MK}, \mathrm{SY}$ & 4 & \\
\hline 27 & pluralis $-l a$ & $\mathrm{MK}, \mathrm{B}, \mathrm{D}, \mathrm{K}$ & 4 & \\
\hline 28 & $* l>r$ & Mgr, MN, K & 3 & \\
\hline 29 & secondary vowel shortening & Mgr, D, K, B & 3 & $\begin{array}{l}\text { Not all Baoan dialects demon- } \\
\text { strate this secondary shortening }\end{array}$ \\
\hline
\end{tabular}




\begin{tabular}{|c|c|c|c|c|}
\hline № & Innovation & Languages & $\begin{array}{l}\text { Number of } \\
\text { languages }\end{array}$ & Comment \\
\hline 30 & ${ }^{*} i>[\eta]$ and $[\eta]$ & Mgr, D, K & 3 & \\
\hline 31 & merge of ACC/DAT $2 \mathrm{Sg}$ & Mgr, MN, B & 3 & Only partly in Mangghuer \\
\hline 32 & future $-n V$ & Mgr, B, D & 3 & \\
\hline 33 & Chinese ordinal number prefix & Mgr, D, K & 3 & $\begin{array}{l}\text { Baoan borrowed ordinal num- } \\
\text { ber prefix from Tibetan }\end{array}$ \\
\hline 34 & pluralis $-s G V$ & $\mathrm{MN}, \mathrm{MH}, \mathrm{MK}$ & 3 & \\
\hline 35 & future $-m$ & $\mathrm{MN}, \mathrm{MH}, \mathrm{B}$ & 3 & \\
\hline 36 & DAT.LOC $-d i$ & $\mathrm{MH}, \mathrm{MK}, \mathrm{SY}$ & 3 & \\
\hline 37 & $*-d>0$ & Mgr, B & 2 & \\
\hline 38 & $-r V$ for the borrowed stems & Mgr, D & 2 & \\
\hline 39 & DIR $-d z i$ & Mgr, MN & 2 & \\
\hline 40 & copula shi & Mgr, D & 2 & \\
\hline 41 & negative particle $\bar{\imath}$ & MN, MK & 2 & \\
\hline 42 & pluralis - $\eta g u /-\eta g u l a$ & $\mathrm{MH}, \mathrm{MK}$ & 2 & \\
\hline 43 & assotiative plurality -mange & $\mathrm{MH}, \mathrm{MK}$ & 2 & \\
\hline 44 & tonal opposition & Mgr & 1 & $\begin{array}{l}\text { Baoan also has tonal opposi- } \\
\text { tion, but tones in Baoan and } \\
\text { Mangghuer emerged inde- } \\
\text { pendently, and it cannot be } \\
\text { considered a shared innovation }\end{array}$ \\
\hline 45 & ${ }^{*}-r>\gamma^{u}$ & Mgr & 1 & \\
\hline 46 & $*-b C->G$ & Mgr & 1 & \\
\hline 47 & splitting of $* y{ }^{*} / \check{c}$ reflexes & Mgr & 1 & \\
\hline 48 & $-t u$ for the borrowed stems & Mgr & 1 & \\
\hline 49 & comparative -her & Mgr & 1 & \\
\hline 50 & non-past -la-Copula & Mgr & 1 & \\
\hline 51 & $\begin{array}{l}\text { tendency to increase number of } \\
\text { clusters }\end{array}$ & MK & 1 & \\
\hline 52 & $\begin{array}{l}\text { tendency to decrease number of } \\
\text { clusters }\end{array}$ & Mgr & 1 & \\
\hline 53 & pronominal LOC -re & $\mathrm{MN}$ & 1 & \\
\hline 54 & intensifier & MK & 1 & \\
\hline 55 & Dualis & MK & 1 & \\
\hline 56 & completive $-d i$ & MK & 1 & \\
\hline 57 & singulative marker with converbs & MK & 1 & \\
\hline 58 & causee ACC & MK & 1 & \\
\hline
\end{tabular}




\section{Conclusions}

These results can be quantified as follows:

Table 16. Number of shared and unique innovations in Monguoric languages.

\begin{tabular}{l|c|c|c|c|c|c|c|c}
\hline & Mangghuer & Naringhol & Halchighol & Karlong & SY & Baoan & Dongxiang & Kangjia \\
\hline Mangghuer & 34 & 15 & 13 & 14 & 8 & 12 & 14 & 13 \\
\hline Naringhol & & 29 & 24 & 23 & 11 & 15 & 10 & 11 \\
\hline Halchighol & & & 28 & 25 & 13 & 15 & 10 & 11 \\
\hline Karlong & & & & 36 & 13 & 14 & 13 & 14 \\
\hline
\end{tabular}

If we count grammatical and phonological innovations separately, we get the following distribution:

Table 17. Distribution of phonological innovations

\begin{tabular}{l|c|c|c|c|c|c|c|c}
\hline & Mangghuer & Naringhol & Halchighol & Karlong & SY & Baoan & Dongxiang & Kangjia \\
\hline Mangghuer & 12 & 3 & 2 & 3 & 2 & 3 & 3 & 5 \\
\hline Naringhol & & 9 & 8 & 8 & 5 & 6 & 3 & 6 \\
\hline Halchighol & & & 9 & 9 & 6 & 6 & 3 & 6 \\
\hline Karlong & & & & 11 & 6 & 6 & 4 & 7 \\
\hline
\end{tabular}

Table 18. Distribution of grammatical innovations

\begin{tabular}{l|c|c|c|c|c|c|c|c}
\hline & Mangghuer & Naringhol & Halchighol & Karlong & SY & Baoan & Dongxiang & Kangjia \\
\hline Mangghuer & 22 & 12 & 11 & 11 & 6 & 9 & 11 & 8 \\
\hline Naringhol & & 20 & 16 & 15 & 6 & 9 & 7 & 5 \\
\hline Halchighol & & & 19 & 16 & 7 & 9 & 7 & 5 \\
\hline Karlong & & & & 25 & 7 & 8 & 9 & 7 \\
\hline
\end{tabular}

We used 58 isoglosses (20 phonetical and 38 grammatical) to study the differences between Monguoric idioms. The data show that the most innovative idiom is Karlong with 36 innovations, followed by Mangghuer (34 innovations). In addition, Karlong is equally distant from other QG non-Mongghul idioms, Mangghuer included. Mangghuer and Karlong are the most innovative idioms in respect to both phonology and grammar. However, as far as phonology is concerned, Mangghuer has developed many unique distinct features whereas phonetical change in Karlong is generally within the areal Tibetan-oriented phonology trend: Karlong has much fewer shared innovations in phonology with Sinitic-oriented Dongxiang and Mangghuer than with other QG languages.

As expected, Mongghul dialects demonstrate a high level of shared innovations (23-25 innovations), and they can hardly be considered separate languages. Mangghuer has more shared innovations with Dongxiang and Kangjia than with SY. Most probably, this is the result of significant Chinese influence on these three languages. On the contrary, the number of innovations shared between Mongghul and Shira Yughur is noticeably larger than the respective number between Mangghuer and Shira Yughur. However, phonological innovations account for most of the difference. Grammatically, Mangghuer is almost at the same distance from SY as Mongghul idioms, but its phonology is much more siniticized. It might be interest- 
ing that the number of Mangghuer - Mongghul shared innovations is not as high (compared to Mangghuer - Dongxiang - Kangjia shared innovations) as one might have expected. However, shared innovations in grammar confirm that Mangghuer is still the closest relative of Mongghul.

\section{Abbreviations}

ABL - Ablative; ACC - Accusative; B - Baoan; CM - Common Mongolic; D - Dongxiang; DAT.LOC - Dativelocative; DIR - Directive; GEN - Genitive; IMPERF - Imperfective; INSTR - Instrumental; K - Kangjia; LOC Locative; Mgr - Mangghuer MK - Karlong; MH - Halchighol; MN - Naringhol; NOM - Nominative; OBJ Objective; PROL - Prolative; QG - Qinghai-Gansu; SG - Singular; SM - de Smedt and Mostaert; SY - Shira Yughur; SUB - Subjective.

\section{References}

Binnick, Robert I. 1987. On the Classification of the Mongolian Languages. Central Asiatic Journal 31: 178-95.

Brosig, Benjamin, Elena Skribnik. 2018. Evidentiality in Mongolic. In: Alexandra Aikhenvald (ed.). Oxford Handbook of Evidentiality: 554-579. Oxford University Press.

Bùhé (布和). 1985. Dōngxiāngyǔ hé Měnggǔyǔ. Hohhot: Nèiměnggǔ rénmín chūbănshè (内蒙古人民出版社).

Bulchulu (保朝鲁) and Jalsan (贾拉森). 1990. Dōngbù Yùgùyǔ hé Měnggǔyǔ. Hohhot: Nèiměnggǔ rénmín chūbănshè (内蒙古人民出版社).

Chén Năixióng (陈乃雄) and Chingeltei (清格尔泰). 1986. Băo’ānyǔ hé Měnggǔyǔ. Hohhot: Nèiměnggǔ rénmín chūbănshè (内蒙古人民出版社).

Chingeltei (清格尔泰). 1986. Tŭzúyŭ Huàyŭ Cáiliào. Hohhot: Nèiměnggǔ rénmín chūbănshè (内蒙古人民出版社).

Chingeltei (清格尔泰) and Ľ̌ Kèyù (李克郁). 1988. Tŭzúyŭ hé Měnggǔyǔ. Hohhot: Nèiměnggǔ rénmín chūbănshè (内蒙古人民出版社).

Chingeltei (清格尔泰). 1989. On Subjective and Objective Mood in the Monguor Language. In: Klaus Sagaster (ed.). Gedanke und Wirkung: Festschrift für Nikolaus Poppe zum 90: 67-75. Geburtstag, Wiesbaden: Otto Harrassowitz.

Chuluu, Üjiyediin. 1994. Introduction, Grammar, and Sample Sentences for Monguor [= Sino-Platonic Papers 57]. Philadelphia: University of Pennsylvania, Department of Asian and Middle Eastern Studies.

Cūi Yŏnghóng (崔永红), Zhāng Dézǔ (张得祖), Dū Chángshùn (杜常顺). 2015. The origin of Monguor. In: Gerald Roche and CK Stuart (eds). Mapping the Monguor. Asian Highlands Perspectives 36: 18-22.

Doerfer, Gerhard. 1964. Klassifikation und Verbreitung der mongolischen Sprachen. In: Bertold Spuler (ed.). Mongolistik (Handbuch der Orientalistik 5.2): 35-50. Leiden: Brill.

Dpal-ldan-bkra-shis, Hu Jun, Hu Ping, Limusishiden, Keith Slater, Kevin Stuart, Wang Xianzheng, Zhu Yongzhong. 1996. Language Materials of China's Monguor Minority: Huzhu Mongghul and Minhe Mangghuer [= SinoPlatonic Papers 69]. Philadelphia: University of Pennsylvania.

Dwyer, Arienne M. 1992. Altaic Elements in the Línxià Dialect: Contact-induced Change on the Yellow River Plateau. Journal of Chinese Linguistics 20: 160-179.

Dwyer, Arienne M. 1995. From the Northwest China Sprachbund: Xúnhuà Chinese Dialect Data. In: Yuen Ren Society Treasury of Chinese Dialect Data, vol. I: 143-82.

Dwyer, Arienne M. 2008. Tonogenesis in Southeastern Monguor. In: Harrison, K. David, David Rood, Arienne Dwyer (eds.). Lessons from documented endangered languages. Typological Studies in Language 78: 111-128. Amsterdam: John Benjamins.

Faehndrich, Bergel Maria. 2007. Sketch Grammar of the Karlong Variety of Mongghul, and Dialectal Survey of Mongghul. $\mathrm{PhD}$ thesis. Honolulu: University of Hawai'i.

Georg, Stefan. 2003. Mongghul. In: Juha Janhunen (ed.).The Mongolic languages: 286-306. London / New York; Routledge.

Gruntov, Ilya, Olga Mazo. 2015. Klassifikacija mongolskix jazykov po lexicostatisticheskim dannym. Journal of Language Relationship 13/3: 205-255.

Gruntov, Ilya, Olga Mazo. 2020. Nominal Morphology: Case and Plurality. In: Martine Robbeets (ed.). The Oxford Guide to the Transeurasian Languages. Oxford University Press (forthc.).

Hasbaatar (哈斯巴特尔). 1985. Tŭzúyŭ Cíhuì. Hohhot: Nèiměnggǔ rénmín chūbănshè (内蒙古人民出版社). 
Hattori, Shiro. 1959 [1993]. A Glottochronological Study of the Mongol Languages. Reprinted in: Selected Papers of Shiro Hattori, vol. 4: Studies in Altaic Languages: 87-8. Tokyo: Sanseido.

Huc, Évariste-Régis. 1850. Souvenirs d'un voyage dans la Tartarie, le Thibet et la Chine pendant les années 1844,1845 et 1846, vols 1-2. Paris: Librairie d'Adrien le Clere et Cie.

Janhunen, Juha. 2003. Proto-Mongolic. In: Juha Janhunen (ed.).The Mongolic languages: 1-29. London / New York: Routledge.

Janhunen, Juha. 2006. The Monguor: The Emerging Diversity of a Vanishing People. In: Louis Schram (Kevin Stuart, ed.). The Monguors of the Kansu Tibetan Frontier [1954, 1957, 1961] Part I: Their Origin, History and Social Organization; Part II: Their Religious Life; Part III: Records of the Monguor Clans: History of the Monguors in Huanchung and the Chronicles of the Lu Family: 26-29. Xining City: Plateau Publications.

Janhunen Juha, Lionel Ha Mingzong, Joseph Tshe dPag rNam rGyal. 2007. On the Language of the Shaowa Tuzu in the Context of the Ethnic Taxonomy of Amdo Qinghai. Central Asiatic Journal 51(2): 177-195.

Janhunen, Juha. 2007. Typological Interaction in the Qinghai Linguistic Complex. Studia Orientalia 101: 85-103.

Janhunen, Juha. 2012. On the Hierarchy of Structural Convergence in the Amdo Sprachbund. In: Pirkko Suihkonen, Bernard Comrie, Valery Solovyev (eds.). Argument Structure and Grammatical Relations: $177-189$. Studies in Language Companion Series 126. Amsterdam: John Benjamins.

Junast (照那斯图). 1981. Tŭzúyŭ Jiănzhì. Běijīng: Mínzú chūbănshè (民族出版社).

Junast (照那斯图), Lŭ Kèyù (李克郁). 1982. Tŭzúyŭ Mínhé fāngyán gàishù. In: Mínzú Yŭwén Yánjiū Wénjí: 458-487. Xīníng. Qīnghăi rénmín chūbănshè (青海人民出版社).

Li, Charles N. 1986. The Rise and Fall of Tones Through Diffusion. In: Proceedings of the Twelfth Annual Meeting of the Berkeley Linguistics Society: 173-185.

Kakudo, Masayoshi. 1987. Tozokugo no Ka’i Hougen. Oosaka Gaikokugo Daigaku Gakuhou 75: 49-63.

Kakudo, Masayoshi. 1997. Tianzhu Tozokugo no Tokuchou: “Geseru Bunko” Daisanken no Shiryou ni Motozuite. Oosaka Gaikokugo Daigaku Ronshuu 17: 33-61.

Khelimsky, Evgenii A. 1984. A distinctive feature that became a phoneme: The case of Monguor. In: $5^{\text {th }}$ International Phonology meeting. Abstracts: 27. Wien.

Kim, Stephen S. 2003. Santa. In: Juha Janhunen (ed.). The Mongolic languages: 346-363. London / New York: Routledge.

Kuzmenkov, Evgenii A. 1993. Mongolskaja bazisnaja leksika v “Sokrovennom skazanii”. In: Mongolica: 328-340. Moskva: Nauka.

Lŭ Kèyù (李克有). 1993. Tŭzú Měnggǔěr Yuánliú Kăo. Xīníng: Qīnghăi rénmín chūbănshè (青海人民出版社).

Lŭ Kèyù (李克郁). 1988. Tŭ Hàn Cídiăn. Xīníng: Qīnghăi rénmín chūbănshè (青海人民出版社).

Lŭ Kèyù (李克郁). 2008. Tŭzú Lìsȟ̌ yǔ Yǔyán Wénzì Yánjiū Wénjí. Běijīng: Mínzú chūbănshè (民族出版社).

Luwsanwandan, Shadawyn. 1959. Mongol xel ayalguunï ucir. Studia Mongolica 1: 1-16.

Lü Jiànfú (呂建福). 2002. Tŭzúshǐ. Běijīng: Zhōngguó shèhuì kēxué chūbănshè (中國社會科學出版社).

Nugteren, Hans. 1997. On the Classification of the "Peripheral Mongolic Languages". In: Árpád Berta (ed.). Historical and Linguistic Interaction Between Inner-Asia and Europe [= Studia Uralo-Altaica 39]: 207-16. Szeged.

Nugteren, Hans. 2003. Shira Yughur. In: Juha Janhunen (ed.). The Mongolic languages: 265-285. London / New York: Routledge.

Nugteren, Hans. 2011. Mongolic Phonology and the Qinghai-Gansu Languages. Utrecht: Lot 289.

Nugteren, Hans. 2013. Postposed indefinite articles in Mongolic and Turkic languages of the Qinghai-Gansu Sprachbund. In: Martine Robbeets, Hubert Cuyckens (eds.). Shared Grammaticalization. With special focus on the Transeurasian languages: 227-250. Amsterdam/Philadelphia: John Benjamins.

Nugteren. Hans. 2014. Amdo Altaic directives and comparatives based on the verb 'to see'. In: Martine Robbeets, Walter Bisang (eds). Paradiom change in the Transeurasian languages and beyond: 243-256. Amsterdam/Philadelphia: John Benjamins.

Poppe, Nicholas. 1955. Introduction to Mongolian Comparative Studies [= Mémoires de la Société Finno-Ougrienne 110]. Helsinki.

Poston, Dudley L., Qian Xiong. 2014. Are China’s Minority Nationalities Still on the Margins? In: Isabelle Attané and Baochang Gu (eds.). Analyzing China's Population: Social Change in a New Demographic Era: 113-138. New York: Springer.

Potanin, Grigorii N. 1893. Tangutsko-tibetskaya okrä̈na Kitaya i central'naya Mongoliya, vols. 1-2. Sankt-Peterburg: Izdanie Imperatorskago Russkago Geograficheskago Obshchestva.

Przheval'skii, Nikolai. 1875. Mongolija i strana tangutov: trekhletnee puteshestvie v vostochnoi nagornoi Aziï. SanktPeterburg: Izdanie Imperatorskago Russkago Geograficheskago Obshhestva. 
Róna-Tas, András. 1960. Remarks on the Phonology of the Mong[uo]r Language. Acta Orientalia Hungarica 10: 263-7. Róna-Tas, András. 1962. On some Finals of the Mong[uo]r Language. Acta Orientalia Hungarica 14: 283-90.

Róna-Tas, András. 1966. Tibeto-Mongolica: The Tibetan Loanwords of Monguor and the Development of the Archaic Tibetan Dialects [= Indo-Iranian Monographs 7]. The Hague: Mouton.

Rybatzki, Volker. 2003. Intra-Mongolic Taxonomy. In: Juha Janhunen (ed.). The Mongolic languages: 364-390. London / New York: Routledge.

Sanzheev, Garma D. 1952. Mongol'skie jazyki i dialekty. Uchenie zapiski Instituta Vostokovedeniya 4: 30-125.

Schram, Louis M. J. 1954-61. The Monguors of the Kansu-Tibetan Frontier: Their Origin, History, and Social Organization, vols 1-3 [= Transactions of the American Philosophical Society, New Series 44/1, 47/1, 51/3]. Philadelphia.

Schröder, Dominik. 1952-3. Zur Religion der Tujen des Sininggebietes (Kukunor). Anthropos 47: 1-79, 620-58, 82270; 48: 202-59.

Schröder, Dominik. 1959-70. Aus der Volksdichtung der Monguor, 1. Teil: Das weisse Glücksschaf (Mythen, Märchen, Lieder), 2. Teil: In den Tagen der Urzeit (Ein Mythus vom Licht und vom Leben) [= Asiatische Forschungen 6, 31]. Wiesbaden: Otto Harrassowitz.

Schröder, Dominik. 1964. Der Dialekt der Monguor. Mongolistik [ = Handbuch der Orientalistik I: V, 2]: 143-58.

Sečenčogt (斯钦朝克图). 1999. Kāngjiāyŭ yánjiū. Shànghăi: Yuăndōng chūbănshè (远东出版社).

Sečenčogt (斯钦朝克图). 2002. Kāngjiāyŭ gàikuàng. Mínzú yŭwén 6: 66-77.

Sinor, Denis. 1952. Langues mongoles. In: Antoine Meillet, Marcel Cohen (eds.). Les langues $d u$ monde (2nd edition): 369-84. Paris: Champion.

Slater, Keith W. 2003a. A Grammar of Mangghuer: A Mongolic Language of China's Qinghai-Gansu Sprachbund [= Curzon Asian Linguistic Series 2]. London: Curzon.

Slater, Keith W. 2003b. Mangghuer. In: Juha Janhunen (ed.). The Mongolic languages: 307-324. London / New York: Routledge.

Slater, Keith W. 2018. Morphological innovations in Mangghuer and Shirongolic: Reconstructing the formal emergence of the subjective vs. objective distinction. In: Simeon Floyd, Elizabeth Norcliff, Lila San Roque (eds.). Egophoricity [Typological Studies in Language, 118]: 225-267. Amsterdam: John Benjamins.

de Smedt, Albrecht, Antoine Mostaert. 1929. Le dialecte monguor parlé par les Mongols du Kansou occidental, Ière partie: Phonétique. Anthropos 24: 145-66.

de Smedt, Albrecht, Antoine Mostaert. 1933. Le dialecte monguor parlé par les Mongols du Kansou occidental, IIIe partie: Dictionnaire monguor-français. Pei-p'ing: Imprimerie de l'Université Catholique.

de Smedt, Albrecht, Antoine Mostaert. 1945. Le Dialecte Monguor. Ile partie: Grammaire. Monumenta Serica 6, Journal of Oriental Studies. Peking: Catholic University.

Tenishev, Edgem R., Buljash X. Todaeva. 1966. Yazyk zheltyx uigurov. Moskva: Nauka (Institut narodov Azii AN SSSR). Todaeva, Buljash X. 1961. Dunsjanskij jazyk. Moskva: Institut narodov Azii AN SSSR.

Todaeva, Buljash X. 1964. Baoan'skij jazyk. Moskva: Institut narodov Azii AN SSSR.

Todaeva, Buljash X. 1973. Mongorskij jazyk: issledovanie, teksty, slovar'. Moskva: Institut narodov Azii AN SSSR.

Wu, Hugjiltu. 2003. Bonan. In: Juha Janhunen (ed.). The Mongolic languages: 325-345. London / New York: Routledge.

$\mathrm{Xu}$, Dan, Wen Shaoqing. 2017. The Silk Road: language and population admixture and replacement. In: Dan Xu, Hui Li (eds.). Languages and Genes in Northwestern China and Adjacent Regions: 55-78. Singapore: Springer Nature.

Zhang, Zhenxing (ed.). 2012. Language Atlas of China. Zhōngguó Yǔyán Ditújí. Shăoshù Mínzú Yǔyán Juăn. 2 ed. Shànghăi: Shāngwù yìnshūguăn (商务印书馆).

\section{И. А. Грунтов, О. М. Мазо. Хуцзу, минхэ и их соседи: оценка степени языковой близости}

Целью настоящей работы является оценка степени языковой близости различных монгольских идиомов в рамках языкового союза Цинхай-Ганьсу, при этом основное внимание уделяется языку минхэ и диалектам хуцзу. На основании 58 грамматических и фонологических совместных инноваций в области фонологии и грамматики авторы пытаются проанализировать основные направления и модели языковых изменений на территории региона.

Ключевые слова: языковой союз Циньхай-Ганьсу; языковые контакты; монгорские языки; минхэ; хуцзу; монгольские языки; совместные инновации; широнгольские языки. 